\title{
KARREN ABOVE CUSTONACI (SICILY, ITALY)
}

\author{
ŠKRAPLJE NAD CUSTONACIJEM \\ (SICILIJA, ITALIJA)
}

\author{
Martin KNEZ ${ }^{1,2,3}$, Rosario RUGGIERI ${ }^{4}$, Tadej SLABE ${ }^{1,2,3}$
}

\begin{abstract}
UDC 551.435.81(450.82)

Martin Knez, Rosario Ruggieri \& Tadej Slabe: Karren above Custonaci (Sicily, Italy)

The extremely interesting karst of the Capo San Vito area in western Sicily displays the majority of the distinct characteristics of the three-dimensional landscape: karst surfaces, caves, unique water trickling systems, and maritime development (Ruggieri, 2009, 2015). By the sea as well as higher in the hinterland, the surface is mostly karren-like. This part of the planned study of the formation of the entire rock surface of this karst presents the results of studying the slope karren above Custonaci. They reveal the development of karren from subsoil karren and the characteristic formation of the karst surface in this area and on this rock.
\end{abstract}

Keywords: karren, lithology, rock relief, Sicily, Italy.

\author{
Izvleček \\ UDK 551.435.81(450.82) \\ Martin Knez, Rosario Ruggieri \& Tadej Slabe: Škraplje nad \\ Custonacijem (Sicilija, Italija)
}

Nadvse zanimiv kras področja Capo San Vito na zahodu Sicilije ponuja večino izrazitih značilnosti trirazsežne pokrajine, kraško površje, jame in svojevrstno pretakanje vode ter obmorski razvoj (Ruggieri 2009, 2015). Površje je večinoma škrapljasto, tako ob morju kot $\mathrm{v}$ višjem zaledju. Tokrat so pri načrtovani proučitvi oblikovanja celotnega skalnega površja tega krasa predstavljeni izsledki proučevanja pobočnih škrapelj nad Custonacijem. Razkrivajo razvoj škrapelj iz podtalnih škrapelj in značilno oblikovanje kraškega površja v tem okolju in kamnini.

Ključne besede: škraplje, litologija, skalni relief, Sicilija, Italija.

${ }^{1}$ Research Centre of the Slovenian Academy of Sciences and Arts, Karst Research Institute, Titov trg 2, SI-6230 Postojna, Slovenia, e-mails: knez@zrc-sazu.si,slabe@zrc-sazu.si

${ }^{2}$ UNESCO Chair on Karst Education, University of Nova Gorica, Glavni trg 8, 5271 Vipava, Slovenia, e-mails: knez@zrc-sazu.si, slabe@zrc-sazu.si

${ }^{3}$ Yunnan University International Joint Research Center for Karstology, Xueyun rd. 5, CN-650223, Kunming, China, e-mails: knez@zrc-sazu.si, slabe@zrc-sazu.si

${ }^{4}$ Hyblean Center for Speleo-Hydrogeological Research, via Torrenuova 87, IT-97100 Ragusa, Italy, e-mail: info@cirs-ragusa.org 


\section{INTRODUCTION}

The study area is situated in the Mt. Sparagio ridge belonging to the northern part of the Monti di Trapani relief in the extreme north-west of Sicily. This territory is bordered to the south by the hills enclosing the towns of Trapani and Castellammare del Golfo and, to the east and west, by the Tyrrhenian Sea (Fig. 1). The territory is predominantly mountainous and its orographic profile is characterized by a series of ridges delimited by coastal plains. Average annual precipitation is $600 \mathrm{~mm}$.

From an environmental point of view this territory is of extreme importance both for its natural beauty and for the biodiversity of its flora and fauna. This is further demonstrated by the fact that this area includes two of the most important Sicilian Nature Reserves: The Riserva Naturale Orientata dello Zingaro and the Riserva di Monte Cofano. However, the zone also includes the second most important marble quarrying industry in Italy, located at Custonaci which, although providing welcome local employment, has certainly brought about a general and serious degradation of the natural environment, as well as interfering with the karst features located in the quarried area.

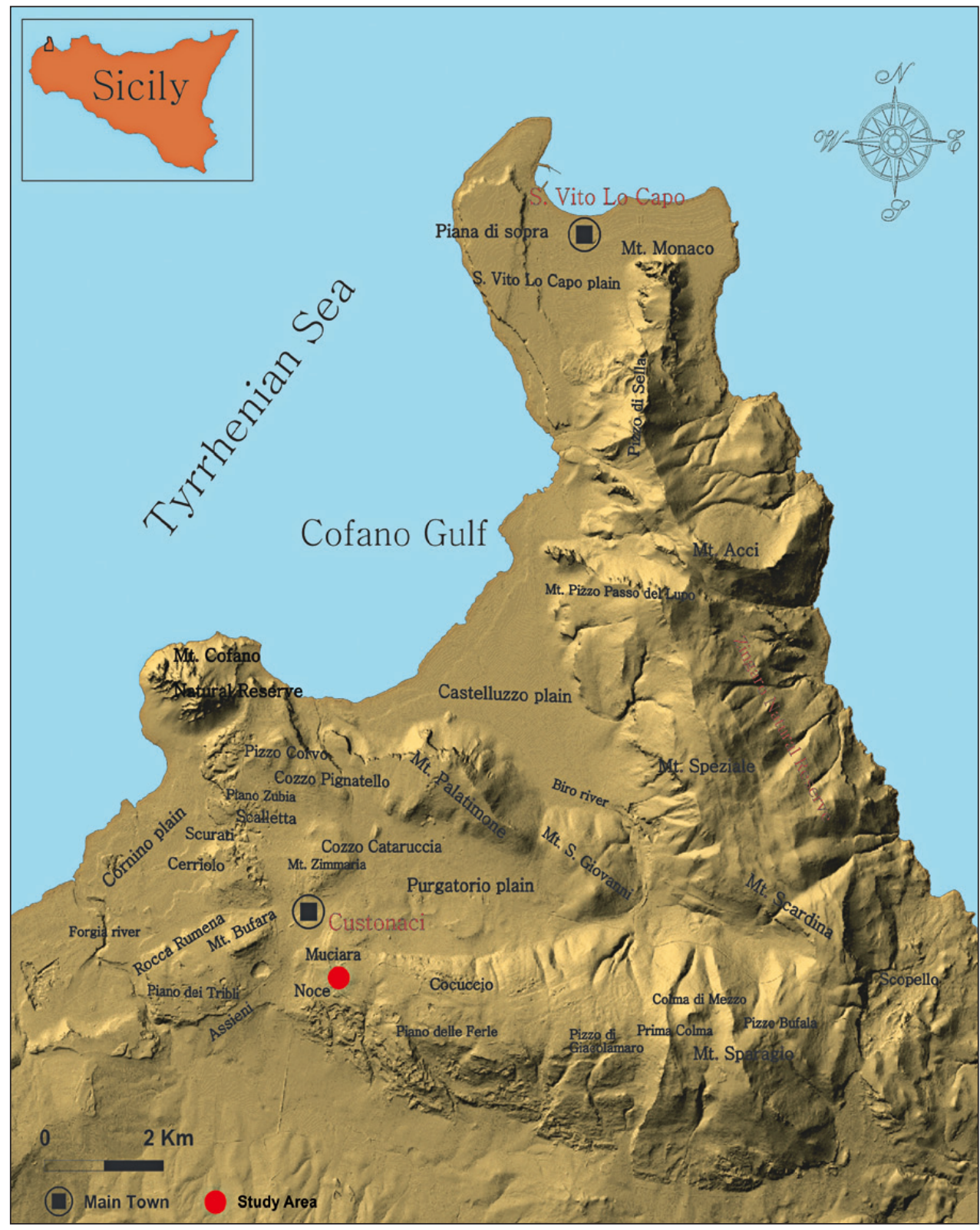

Fig. 1: Study area is situated in the Mt. Sparagio ridge belonging to the northern part of the Monti di Trapani relief in the extreme north-west of Sicily. 


\section{GEOMORPHOLOGICAL FEATURES}

From the morphological point of view in this sector some major areas of different landforms were recognized.

The coastal areas of Cornino, a plain stretching from 0 to $100 \mathrm{~m}$ a.s.l. and bordered to the S-W by the Forgia stream, to the $\mathrm{N}-\mathrm{E}$ by the slopes of Mt. Cofano, to the east by the rocky cliffs of Scurati - Cerriolo - Rocca Rumena and to the west by the sea. The plain is characterized by a series of marine terraces, consisting of platforms at different levels, and formed by the abrasion of sea water. The terraces are, sometimes covered by continental or marine deposits and separated from each other by modestly sized banks and irregular cliffs. They have been carved by sea-notches, or more frequently, by shelters and caves, both of marine and karst in origin (Ruggieri 2015).

The Purgatorio plain, a large depression, including a relict polje, formed not only due to selective processes resulting from the presence of clay and karst soluble terrains in the area between the carbonate outcroppings of Mt. Sparagio and Mt. Palatimone, but also as a result of tectonic processes pointed out by systems of faults. This depression, which is opened with a deep fluviokarst gorge along its north-west margin, is particularly karstified with surface and underground morphologies, many of which are among the most interesting in the area (Ruggieri 2015).

The Mt Palatimone - Mt. San Giovanni ridge, with their respective maximum peaks of 595 and $455 \mathrm{~m}$ a.s.l., a cuesta monocline relief of Mesozoic dolomite extend- ing NW-SE and with a southern side that links up with a structural slope. This area shows a vast amount of surface karst morphologies, particularly along the southern structural slope together with numerous vertical caves located on both sides of the ridge.

The Mt. Monaco - Mt. Speziale ridges, oriented towards the N-S and with peaks of 532 and $943 \mathrm{~m}$ a.s.l. respectively. These areas are prevalently made up of Upper Triassic dolomitic rocks and are essentially characterized by two types of landscape: the summit areas where ancient relict forms have been preserved and the slopes where the processes of degradation and denudation predominate.

The Monte Sparagio ridge, where the study area is located, a formation of Mesozoic carbonate rocks that develops in a WNW-ESE direction and reaches a peak of 1,110 m a.s.l., the highest point in the Capo San Vito mountain system. Along the northern face, a large fault slope is visible, while the southern side is characterized by an eastern sector exhibiting structural slopes and a western sector constituted by an upper slope and by numerous other fault scarps. The summit areas (situated at altitudes from 190 to $900 \mathrm{~m}$ a.s.1.) consist of steps of more or less flat surfaces, probably formed by erosion during the 'planation' in the continental phase. Both the flat areas and the slopes are of particular interest for their various karst morphologies, such as karren, dry valleys and deep fluviokarst canyons (Ruggieri 2015).

\section{GEOLOGICAL AND STRUCTURAL SETTING}

In the Central Mediterranean region the AppenninicMaghrebian Orogen originated during the Tertiary by the convergence between the European and the Africa-Adria Plates. In Sicily this orogen, corresponding to a thrust belt-foredeep-foreland system (Ogniben 1960; Broquet \& Mascle 1972; Catalano \& D’Argenio 1978, 1982), extends with dominant E-W trend from the Trapani Mts. to the Peloritani Mts. and is formed by a stack of imbricate foreland-verging folds and related thrust sheets (Bianchi et al. 1987; Roure et al. 1990; Catalano et al. 2000).

In this area, according to Abate et al. (1991, 1993, 1996, 1998), six major tectonic units, crop out in this area stacked after the Middle Tortonian, with stepped rampflat thrust geometries (Incandela 1995), while according to Catalano et al. (2011) two main tectonic units have been observed: U.S.S. Monaco-Sparagio and U.S.S. Acci.

During the Early Pliocene new thrusts and back- thrusts were produced (Giunta \& Liguori 1972; Abate et al. 1991, 1993; Incandela 1995). The structural analysis revealed at least two fold generations. The older system is oriented N-S and NE-SW and is probably associated with Miocene thrusting. This system is reoriented by an E-W trending superimposed fold system, which is probably related to the Pliocene thrusting. The northern vergence of several large scale folds (Acci Mt., Sparagio Mt., etc.) is probably associated with the Pliocene back-thrusting (Abate et al. 1991, 1993).

From the beginning of the Early Miocene, the units previously pertaining to the old Tethys margin (basins and carbonate platforms) were rotated during deformations and nappe emplacement. As a result of this orogenic phase, transpressive structures developed (Oldow et al. 1989).

Since Middle Pliocene strike-slip tectonics affected 
the tectonic pile resulting in a NW-SE/W-E trending dextral fault system and a N-S/NE-SW trending leftlateral fault system. These faults cut pre-existing thrust fronts and produced drag folds and minor thrust; they also produced transpressional structural highs (flower structures) and transtensional depressions (pull-apart basins) filled with Pliocene-Pleistocene deposits. The former structures linked to the dynamics of the Tyrrhenian opening, which migrated south-eastward (Abate et al. 1998; Nigro \& Renda 2005).
The flight of Pleistocene marine and continental deposits suggests the persistence of transpressive tectonic activity until the present time (Abate et al. 1998; Nigro at al. 2000; Tondi 2007).

The sedimentary succession cropping out in this territory consists mainly of Upper Triassic to Pliocene carbonates. The carbonates show platform from open reef to basinal facies.

\section{SITE AND SHAPE}

The studied karren are on a slope of the Noce area in the Mt. Sparagio edge (Figs. 2, 3) and at the upper edge of the slope which continues to a plateau-like karst elevation. On the lower part of the slope, individual rocks and rock teeth protrude from the soil as well as larger rock outcroppings in places. They are up to 1.5 meter in height and rounded or conical in shape. In the middle section there are more rock surfaces, the rock teeth are oblong and lie across the slope. The upper edge is all rock and dissected in mostly more extensive, up to 10 meters or wider, rounded stone hills and somewhat smaller rock pillar with walls up to 10 meters high. The rounded hills are dissected by corrosion along vertical fissures. The rocky rounded hills and pillars as well as the rock teeth originated between fissures that crossed the slope, hence their oblong shape. Often the rock pillars found at the rim of the elevation continue with a belt of rock teeth below them to the rock ribs of the slope. Larger slope notches developed along the more distinct ribs. At the western edge of the rock mass, there is a horizontal notch under a vertical wall. Larger rock masses up to 5 meters in height are found on the top, frequently arranged in belts between fissures. The peaks that formed along bedding planes below thinner or more rapidly disintegrat-

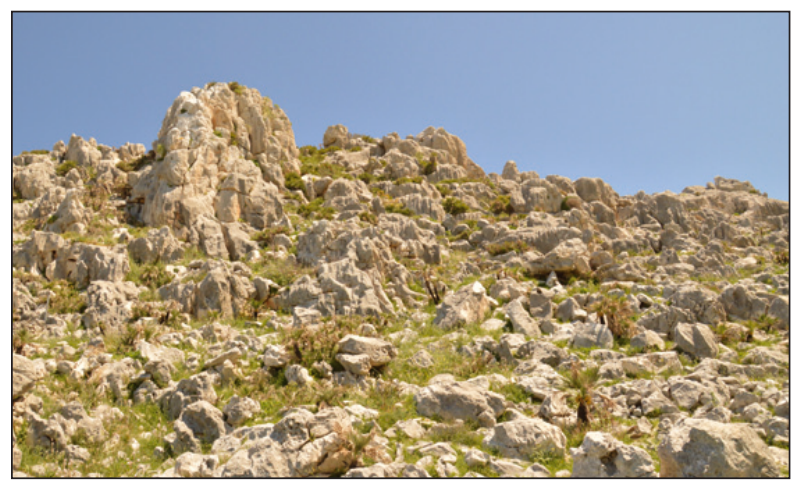

Fig. 2: Slope of Noce area in the Mt. Sparigo edge (Photo: M. Knez).

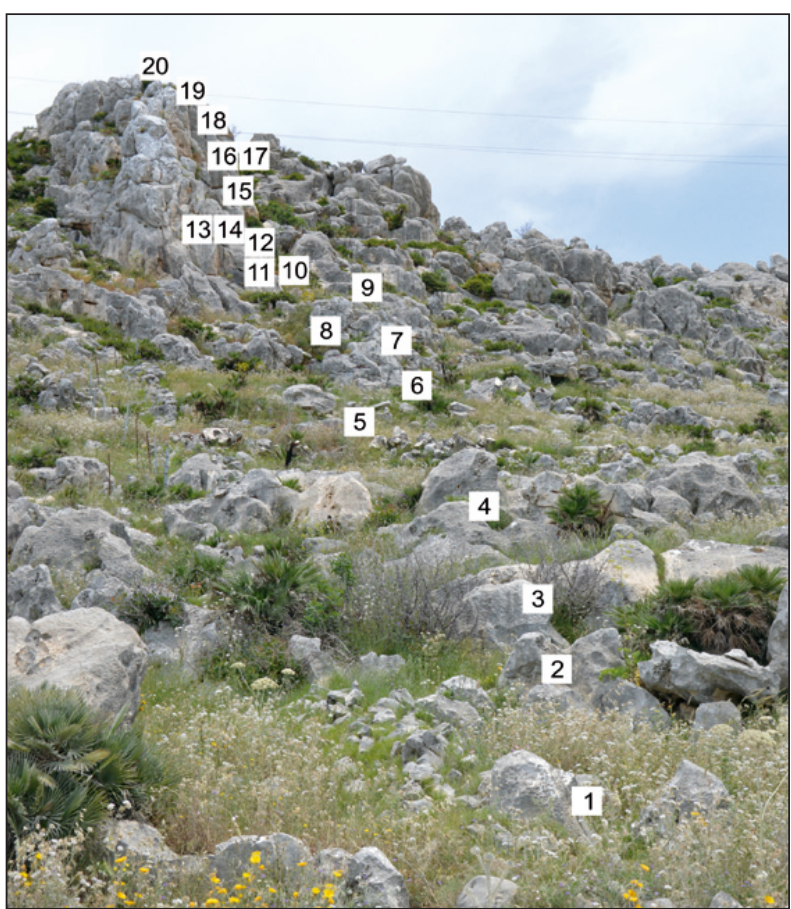

Fig. 3: Studied karren with locations of taken rock samples (Photo: M. Knez).

ing strata of rock are flat. The dissected tops of smaller rocks formed along a denser network of fissures and of larger ones that have been denuded for a longer period are sharp. In the former this is primarily the consequence of subsoil origin. The lateral roundness of the rocks, especially the larger ones, is the dominant feature.

The karren are relatively densely perforated. Smaller cavities a few centimeters in diameter, which in most cases formed along thin fissures and bedding planes, occur individually or hollow individual parts or the entire rock of rock teeth in a dense system (Fig. 4a). Some of them formed under the soil and have round or elliptical 

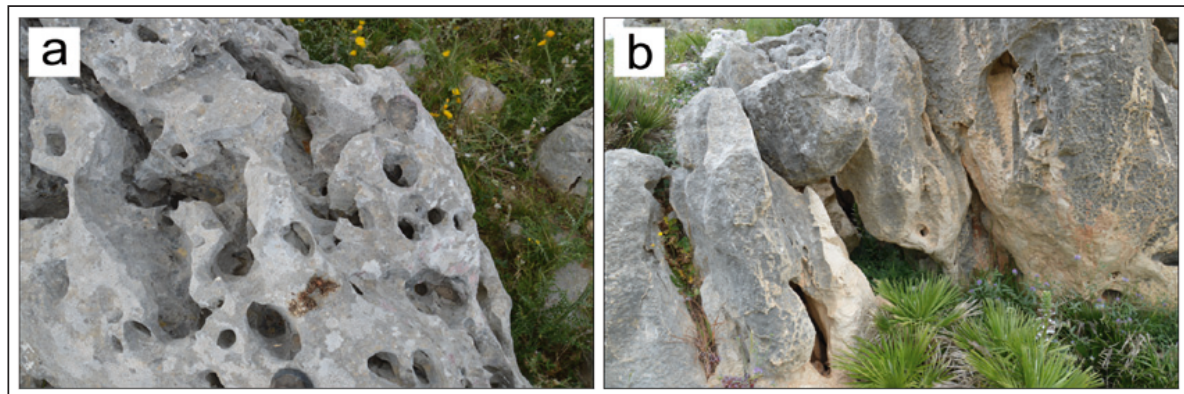

Fig. 4: Cavities: a. dense net of cavities; $b$. subsoil cavities, transformed by rain and percolating water; $c$. vertical subsoil cavity, reshaped by rain; $d$. cavity, along vertical fissure; $d$. subsoil transformed bottom of cavity (Photo: T. Slabe).
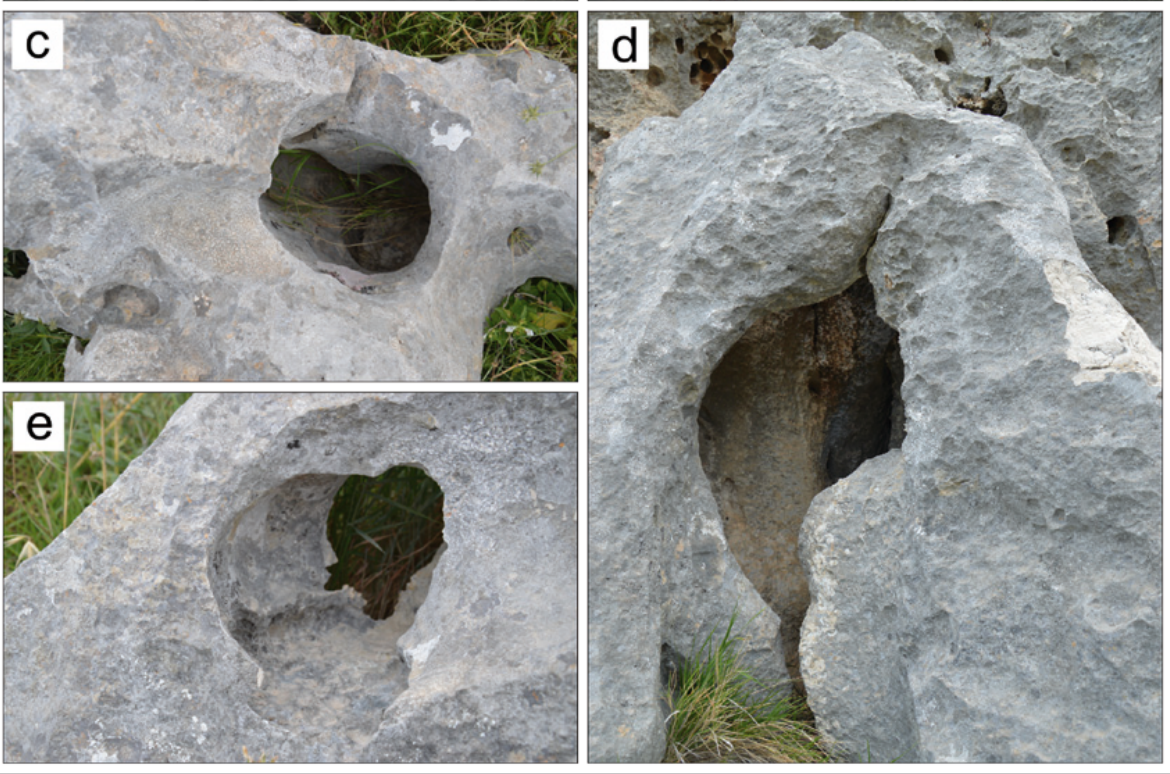

cross-sections and smooth walls because they were only recently denuded, while others were formed by percolating water that reshaped earlier denuded karren (Fig. $4 b)$. Some cavities are larger with diameters exceeding one decimeter. These as a rule are also of subsoil origin; if they are vertical in the form of shafts, they are later reshaped by water trickling down their walls (Fig. 4c). Their mouths widen into funnels. The lower sections of cavities on rock teeth, the shorter rocks, are still filled with soil. They can be wider at the level of the soil or above it. Some cavities, especially along bedding planes, formed in the locally saturated zone. In places, they achieve diameters of one meter, particularly those of elliptical shape. Some are above-sediment raised, while others are reshaped on the bottom with channels (Fig. 4d, e).

Springs of water that percolate through them are found on the walls of the larger rock masses. Wall channels are found below smaller cavities.

The three-dimensional development of the karren and their perforation is very evident as well in the crosssections of the epikarst in a nearby quarry.

Grass and shrubs are found between the rocks.

\section{GEOLOGY}

\section{MACROSCOPIC DESCRIPTION}

A carbonate profile about $90 \mathrm{~m}$ thick running in a northeast-southwest direction was studied in detail. The rock ranges from thickly layered to massive with massive rock dominating. The layers, mostly several tens of centimeters thick, are only rarely visible.
In the lower and middle section of the profile, where the inclination of the surface averages between 30 and 40 degrees, larger rock outcroppings appear on the surface with no regular order (Fig. 3). In many places, larger surfaces between blocks of rock are covered by fragments of rock that broke off from higher sections of the slope and 
grass grows between the fragments. On the near-vertical section of the profile, there is no covering of the bedrock and the slope karren are most visible here.

The dip angle of the beds can only be measured in a few places from the foot to the top of the studied profile and it varies with a prevalent westward dip between $5^{\circ}$ and $20^{\circ}$. The direction of the dipping beds is between $210^{\circ}$ and $340^{\circ}$. Heavy fissuring is visible throughout the rock. Numerous mostly subvertical faults, fault zones, fissures, and calcite veins run in all directions, but mostly in the northeast-southwest direction. The fissures and faults have been widened due to gravity and corrosion. In places where numerous fissure and fault zones are heavily crushed, the rock tends to weather and karstify more rapidly. In most cases the surfaces of relatively hard and less fissured rock as well as numerous fragments on the slope of the profile do not have sharp edges but instead, the rock is softly rounded. In places the rock is slightly bituminous. A light brown colour (N8,5YR 8/1, 5YR 7/2; Munsell Color, 2009) is dominant on the rock.

\section{MICROSCOPIC DESCRIPTION}

Twenty rock samples were taken from the profile and studied under the microscope. In particular we were interested in the occurrence in a network of cylindrical holes of bio-corrosion origin in the middle section of the profile between samples 5 and 12 .

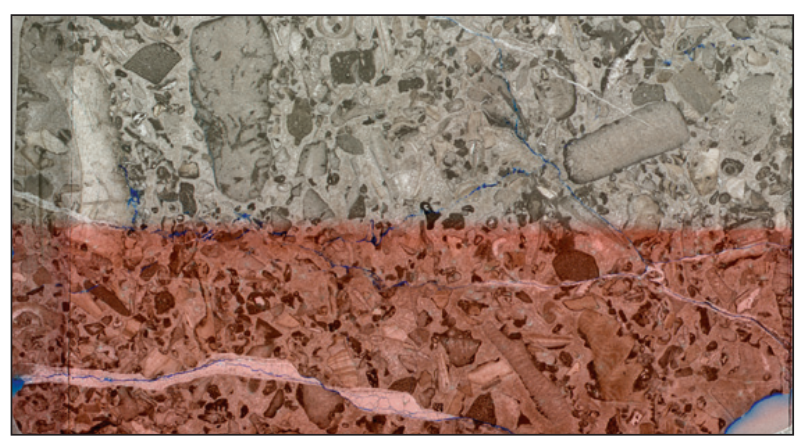

Fig. 5: Blue epoxy rasin imprinted in the rock slice prepared for thin section (Photo: F. Drole).

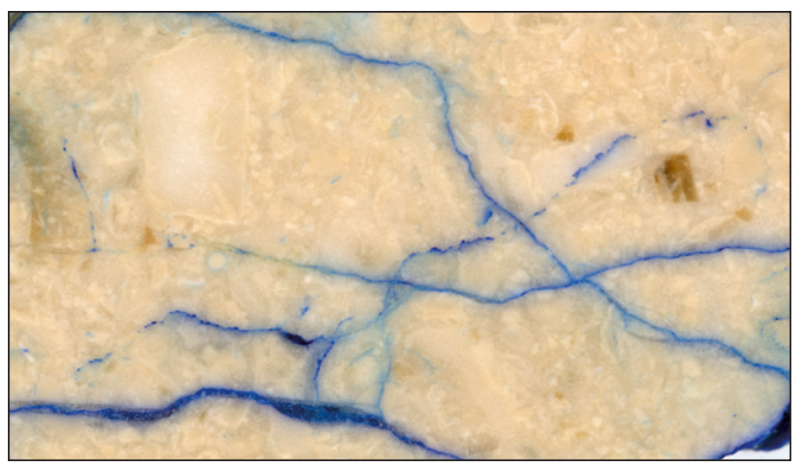

Fig. 6: Thin section made of rock slice seen on Fig. 5 (Photo: F. Drole).
Blue epoxy resin was imprinted in the $5 \mathrm{~mm}$ thick rock slices prepared for making thin sections. After polishing, the rock slices were described and later compared to the corresponding thin sections (Figs. 5, 6), that is, we compared the area of the blue epoxy resin visible on the rock slices prepared for making the thin sections and the area of the blue epoxy resin later measured on the thin sections.

Twenty-seven thin sections were prepared from the tiles of the 20 rock samples and studied with transmitted light microscopy. Prior to the microscopic analyses, half of each thin section was dyed with alizarin red (1,2-dihydroxyanthraquinone, also known as Mordant Red 11, Evamy \& Sherman 1962). Together with the results of the complexometric analysis we successfully identified the characteristics of the rock.

In the geological profile the rock is very uniform and thus has a uniform composition. No potential rock sections were observed in the profile that would lithologically or stratigraphically divide the studied profile into several parts. However, each studied bed has its own micro characteristics. Some beds have larger carbonate grains, others smaller grains, some contain more detrital grains, and others more whole and fragmented fossil remains. Some beds are more fractured, other less. The size, type, binding, quantity of whole and fragmented fossils, and cementation of the rock samples taken and their thin sections show potential, possibly only apparent cyclical or alternating content of carbonate grains in the rock.

Perhaps most characteristic for the studied section of the geological column is the change in porosity, which increases from sample 10 upwards.

All the studied beds are calcarenite to calcirudite, a limestone rock with more than a half of presedimented carbonate grains the size of sand $(0.0625$ to $2 \mathrm{~mm}$ in diameter) or carbonate grains larger than the size of sand (more than $2 \mathrm{~mm}$ in diameter). The size and composition of carbonate grains in calcarenite, which is the rock equivalent of sandstone, has a significant influence on the manner of karstification and the possibility of the formation of features on the rock (e.g., rain flutes). Mainly whole and fragmented mollusks dominate in the fossil remains, while in individual beds there are numerous foraminifers and various intraclasts of presedimented rocks.

The profile begins (Samples 1 and 2) with biointramicrite calcarenite (grainstone to packstone). It contains bioclasts (mollusk fragments) about one centimeter in size and individual large foraminifers and fragments of various other fossils that dominate in the beds. Intraclasts of older rocks are somewhat fewer in number. Pelloids occur only exceptionally. Carbonate grains show no sorting, roundness, or other texture forms. In some plac- 
es umbrella porosity is evident. Numerous fenestrae are filled with mosaic sparry drusy calcite, which in places is partly microsparitic and also binds all the carbonate grains. Complexometric titration analysis was used to establish around $2 \%$ dolomite in the beds, which was not successfully observed in the thin sections. The blue epoxy resin revealed the fracture porosity along many fissures.

Beds (Sample 3) of typical calcarenite with numerous intraclast fragments of non-biogenic origin and numerous whole foraminifers and their fragments (grainstone) follow. In most cases, the bioclasts, intraclasts, and individual plasticlasts do not touch each other but are bound by mosaic sparry drusy calcite as cement. Bioclasts and intraclasts together occupy almost half of the rock volume. Porosity in the rock is not observed, and there are no calcite veins or fissures. These beds alternate with thinner beds of calcirudite (Sample 4).

Next in the geological profile is a thicker section of calcarenite (Samples 5 to 12); this is the section of the studied profile where holes of biocorrosion origin occur connected in a network. About one half of the rock's volume is occupied by whole and fragmented bioclasts, and the other half by intraclasts (grainstone). Mollusks occur as fragments while large foraminifers are mostly whole. For the first time, the profile displays the cross-sections of solitary corals. Carbonate grains show no sorting, roundness, or other texture forms. Mosaic sparry drusy calcite binding bioclasts and intraclasts often changes into partial microsparite. Complexometric titration analysis determined about $2 \%$ dolomite in all the beds, which was not evident in the thin sections. Tiny calcite veins and fracture porosity are more frequent. In between we detected several beds that contain fragments of mollusks and corals about one centimeter in size as well as individual large foraminifers and fragments of various other fossils that dominate in the beds (Samples 9 and 11). There are fewer intraclasts of older rock and pelloids. The carbonate grains show no sorting or roundness.

Thin sections 13 and 14 (these samples were taken two meters apart in the same bed) show minor differences in the carbonate grain composition. Sample 13 had about $5 \%$ fracture porosity with numerous fragments of large foraminifers and fenestrae along fissures filled with mosaic sparry drusy calcite. Sample 14 shows no fracture porosity, and larger than average bio-and intraclasts are bound by mosaic microsparry calcite and micrite calcite as cement. Microscopic analysis showed only minor lateral changes.

Thin sections 16 and 17 (these samples were taken six meters apart in the same bed) are almost completely identical calcarenites containing mostly whole and fragmented foraminifers and rock fragments.

The geological profile continues (Samples 17 to 20) to the top with no significant lithological changes. Beds of calcarenite and calcirudite alternate, and there are changes in the size and quantity of intraclasts and bioclasts and in the size of crystals in the binding mosaic sparry drusy calcite.

In all of the samples we observed a significant difference between the surface of the imprinted blue epoxy resin on the surface of the cut rock tiles that were prepared for making the thin sections and the surface of the blue epoxy resin measured later on the thin sections. Prior to the process of making the thin sections, the cut rock tiles on which the blue epoxy resin was imprinted were additionally polished a few $\mu \mathrm{m}$ once more in order to level the surface. The measured surface of the epoxy resin visible in the thin sections is significantly smaller than the surface measured on the tiles. On the thin sections the blue epoxy resin is visible primarily only in fissures, in a narrow belt in the middle of multi-generation calcite veins, and at the contacts between larger clasts.

It was determined that the cause for the reduced surface of blue epoxy resin on the thin sections was the polishing of the rock tiles a few $\mu \mathrm{m}$ prior to making the thin sections. The porosity established using the blue epoxy resin is closed except along the fissures and at the contacts of larger clasts.

\section{COMPLEXOMETRIC TITRATION ANALYSES}

Because at the macroscopic level we were not able to establish whether in individual sections of the studied profile the rock is potentially dolomitized, and if so, to what degree it is dolomitized and if it contains a larger quantity of insoluble particles, we performed complexometric titration analyses employing the dissolution method (Engelhardt et al. 1964). The analyses were performed using the standard procedure on 20 rock samples or their parts. The results of the analyses show a high content of total carbonate (Tab. 1).

We determined that the lowest content of total carbonate in samples from the profile is $95.37 \%$ total carbonate. Four samples have total carbonate content between $94 \%$ and $95 \%$, four between $96 \%$ and $97 \%$, six between $97 \%$ and $98 \%$, and six between $98 \%$ and $99 \%$. The average value for all the samples exceeds $97 \%$. All the samples have a high percentage of calcite with only five samples having less than $97 \%$ calcite, and the average value of calcite for all the samples is almost $97.5 \%$. All of the samples also contain a low percentage of dolomite. Thirteen samples have less than $2 \%$ dolomite, one less than $1 \%$, and one between $3 \%$ and $4 \%$. The average value for dolomite in the samples amounts to $1.8 \%$. Similarly low is the percentage of insoluble residue. In two samples the value for insoluble residue is between $3 \%$ and $4 \%$, in five samples it is between $2 \%$ and $3 \%$, and in thirteen 
Tab. 1: Complexometric titration analysis of rock samples.

\begin{tabular}{|c|c|c|c|c|c|c|c|}
\hline Rock sample & $\begin{array}{c}\mathrm{CaO} \\
(\%)\end{array}$ & $\begin{array}{c}\text { MgO } \\
(\%)\end{array}$ & $\begin{array}{c}\text { Dolomite } \\
(\%)\end{array}$ & $\begin{array}{c}\text { Calcite } \\
(\%)\end{array}$ & $\begin{array}{c}\text { Total } \\
\text { carbonate }(\%)\end{array}$ & $\begin{array}{c}\text { CaO/MgO } \\
\text { insoluble } \\
\text { residue (\%) }\end{array}$ \\
\hline TR 1 & 54.51 & 0.48 & 2.21 & 96.07 & 98.28 & 113.56 & 1.72 \\
\hline TR 2 & 54.90 & 0.32 & 1.47 & 98.65 & 97.18 & 171.56 & 1.3 \\
\hline TR 3 & 54.90 & 0.24 & 1.06 & 98.48 & 97.42 & 228.75 & 1.5 \\
\hline TR 4 & 54.51 & 0.48 & 2.21 & 96.07 & 98.28 & 113.56 & 1.72 \\
\hline TR 5 & 54.73 & 0.32 & 1.47 & 98.34 & 96.87 & 171.03 & 1.6 \\
\hline TR 6 & 54.67 & 0.48 & 2.21 & 97.65 & 98.57 & 113.90 & 1.43 \\
\hline TR 7 & 54.90 & 0.32 & 1.47 & 98.65 & 97.18 & 171.56 & 1.3 \\
\hline TR 8 & 54.45 & 0.40 & 2.77 & 95.24 & 98.01 & 136.13 & 1.99 \\
\hline TR 9 & 54.67 & 0.36 & 1.66 & 98.32 & 96.66 & 151.86 & 1.6 \\
\hline TR 10 & 54.79 & 0.36 & 1.66 & 96.87 & 98.53 & 152.19 & 1.47 \\
\hline TR 11 & 54.90 & 0.40 & 1.84 & 98.81 & 96.97 & 137.25 & 1.1 \\
\hline TR 12 & 54.84 & 0.32 & 1.47 & 97.61 & 98.53 & 171.38 & 1.47 \\
\hline TR 13 & 54.73 & 0.08 & 0.37 & 97.85 & 97.48 & 684.12 & 2.1 \\
\hline TR 14 & 54.06 & 0.44 & 2.03 & 97.40 & 95.37 & 122.86 & 2.6 \\
\hline TR 15 & 54.06 & 0.40 & 1.84 & 97.32 & 95.48 & 135.15 & 2.6 \\
\hline TR 16 & 54.06 & 0.32 & 1.47 & 97.15 & 95.68 & 168.93 & 2.8 \\
\hline TR 17 & 54.06 & 0.44 & 2.03 & 97.40 & 95.37 & 122.86 & 2.6 \\
\hline TR 18 & 54.79 & 0.28 & 1.29 & 98.37 & 97.08 & 195.68 & 1.6 \\
\hline TR 19 & 54.40 & 0.28 & 1.29 & 97.67 & 96.38 & 194.28 & 3.4 \\
\hline TR 20 & 53.94 & 0.40 & 3.68 & 94.79 & 97.00 & 134.85 & 3.00 \\
\hline
\end{tabular}

below $2 \%$. The average value for insoluble residue in all samples is $1.9 \%$.

\section{IMPACT ON KARSTIFICATION}

Relative to the macroscopic and microscopic studies of the rock, it was established that the entire geological profile, all the beds building the studied profile, react in a similar way to karstification.

Despite the occasional macroscopically different rock where we took samples, it turned out that throughout the entire thickness of the studied geological column, the rock has a very consistent and uniform composition. The microscopic analysis of rock taken from the same beds indicated only minor differences regarding lateral changes in the bed.

The rock is composed of carbonate grains the size of sand ( 0.0625 to $2 \mathrm{~mm}$ in diameter, calcarenite) and carbonate grains larger that the size of sand (more than $2 \mathrm{~mm}$ in diameter, calcirudite). The size and composition of the carbonate grains in calcarenite, which as a rock resembles sandstone, the type of the binding, and frequently carbonate grains that are considerably larger than $2 \mathrm{~mm}$ have a significant impact on the manner of karstification and substantially reduce the possibility of the formation of rock forms (for example, rain flutes).

\section{ROCK RELIEF}

\section{SUBSOIL ROCK FORMS}

Rock forms reveal the development of karren from subsoil rock forms. They often dominate the rock relief of smaller rocks still surrounded by soil (Fig. 7a); on larger rocks they are often limited to the lower sections while higher up they are reshaped. Young denudation is revealed by rounded rock surfaces and their smoothness. The larger subsoil rock forms are funnel-like notches in which water accumulates and then runs off downwards.
The notches can reach a meter in diameter. Below them are wall channels of decimeters in diameter (Fig. 7b). They often dissect ridges into many smaller peaks (Fig. 7c). In places smaller subsoil shafts formed along fissures at the bottom of deeper notches. Some have only a narrow outside opening. The walls can be dissected along the mouths of numerous cavities. Larger funnel-like notches are often dissected by smaller notches or half-bells that developed below smaller cavities. They are most often 
widened along long-term soil levels. In places they developed from subsoil cups or vertical cavities at the edge of the top. At the bottom of individual funnel-like notches there are subsoil cups still filled with soil (Fig. 7d).

Longitudinal notches that bear witness to longlasting levels of soil surrounding the rock are the most distinct in places at the foot of larger rock pillars. The best preserved are those just above the ground (Fig. 7a). Smaller, channel-like longitudinal notches less than one meter in diameter dominate, indicating the even flow of water on the contact. Widened depressions or half-bells only form under continuous water flows down channels
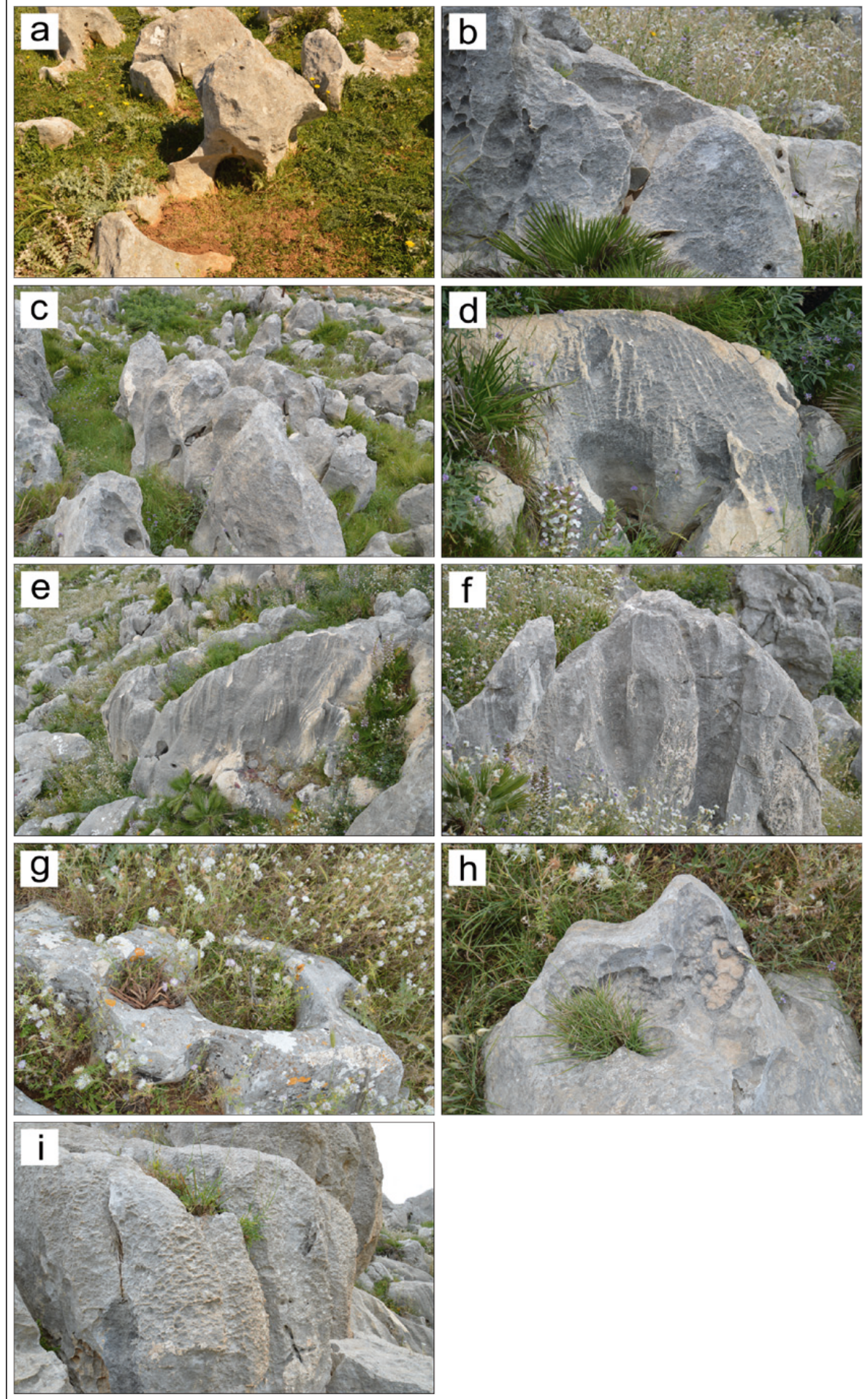

Fig. 7: Subsoil rock forms: a. subsoil notches, subsoil cavity, subsoil funnel-like notches, subsoil channels; b. subsoil funnel-like notch; c. subsoil funnel-like notches and subsoil channels; $d$. subsoil funnellike notch and rain flutes above; e. subsoil funnel-like notches, and half-bells, reshaped by rain; f. subsoil funnel-like notch with subsoil channels; g. subsoil cups; h. denuded subsoil cup with smaller cups on bottom; i. subsoil cup with outflow channel (Photo: T. Slabe). 
or through cavities to the contact, which indicates a more distinct dissolving of the rock in places. Larger cups more than one meter in diameter are found in places on the walls of larger pillars and are traces of former long-lasting levels of soil surrounding the rock. Half bells (Fig. $7 \mathrm{e}$ ) occur below vertical channels or below cracks along the fissures. The latter are often deeper and widened along bedding planes.

Subsoil channels (Fig. 7f) are often found on walls below funnel-like notches and subsoil cavities. They run straight downward or meander on the wall, as dictated by the permeability of the contact.

Subsoil cups and channels occur below the soil that in places covers the rock (Slabe \& Liu 2009). The largest are found between rock teeth in the lower section of the karren. They are completely covered by soil and difficult to distinguish from subsoil cracks. Their edges are dissected by funnel-like notches, channels, and half-bells. Smaller ones are found on the rock teeth (Fig. 7h). They are still filled with soil or already denuded. The smallest have about one centimeter large semi-circular crosssections and often flat bottoms. Only individual ones are three-quarter-circular and therefore have openings smaller than their diameters. Somewhat larger ones with about one decimeter cross-sections are channel-like if they developed rapidly downward or display narrower openings and wider lower parts if they developed longer in the same spot. Some developed as roofless cavities. Along fissures their cross-sections are elliptical. Those lying close together can merge over time. They are often found at the bottoms of funnel-like notches and cavities (Fig. 7d). A run-off channel can lead from them. Such subsoil cups with various degrees of openness are found particularly on rock slopes where they can develop directly into funnel-like notches on the outer side (Fig. $7 \mathrm{~h}, \mathrm{i})$. Subsoil cups, ranging in diameter from several millimeters to two centimeters, were able to dissect the bottoms of open solution pans (Fig. 7h), particularly if water carried soil from higher-lying subsoil rock forms and cavities. In the belt of creeping water they cascade one below another in places. Such also are several funnellike notches with cups on their walls and bottoms. On the walls they are open while on the floor they are semicircular. This type of cup is often partly filled only periodically when their bottoms are covered by a thin layer of sediment. As a rule, they lie side by side connected in a network. Larger ones, about a centimeter in diameter, in places dissect smaller ones whose diameters are only a few millimeters. These are composite rock forms carved by water trickling down the wall and dissected by corrosion under a thin layer of sediment.

Subsoil channels occurring below the soil that covers the rock in places reach diameters about a decimeter in size and have semi-circular cross-sections. The largest are half a meter deep and occur on the rocks before subsoil cavities. As a rule, wall channels are found below channels that lead to the edge of a gently sloping top. They are frequently dissected by cross-steps that develop when soil is carried from the top and deposited on the wall. Periodically it covers small ledges and thus protects them from corrosion. Smaller subsoil channels connect subsoil cavities and pockets.

\section{BIOCORROSION ROCK FORMS}

Networks of cylindrical holes comprise one of the most unique rock forms of these karren. They occur on all the karren in the wider surroundings along the sea as well as in the hills above it. The diameter of the networks is measured in decimeters. They are composed of cylindrical holes several centimeters wide and up to several decimeters deep (Fig. 8a, b, c). The holes can be straight or winding, and they lie side by side. They occasionally branch out inside. Their inner ends are semi-spherical (Fig. 8c). The system hollows the rock in the shape of a tuber. Such holes are only rarely found individually or in a smaller group. Often there is a larger hole at the start of the system that branches into cylindrical holes. Some holes continue into narrower holes. Most of them are found on walls, especially on overhanging (Fig. 8a) ones where they lead upwards, but they are also found on the ground and lead downwards. Quettier $(2011,201)$ established that such forms only exist on areas of rock that rainwater and creeping water do not reach or flood. Can the latter be the remains on a rockfall? The interior surface of the holes is smooth and yellow-brown in color. On walls and ceilings they are empty or occupied by snails (Fig. 8d). If they are on the ground, their lower part is often shaped like a partially filled subsoil cup.

Cylindrical holes are of similar size and have "regular" shapes unlike subsoil cups and cavities that have various shapes and sizes. In places, these rock forms are intertwined.

Several stages in their disappearance due to rainwater and creeping water that characteristically reshapes the surface of the rock can be traced (Fig. 8e, f) . In places only the deepest parts of cylindrical hole systems as a rule are preserved on the walls, appearing from the side to resemble channels; elsewhere, their last remains comprise a network of holes dissecting the walls of shallow depressions. Solution pans developed in places from those on the ground.

Everything points to a biocorrosion origin. It is clear from descriptions and pictures (Mietto \& Sauro 2003; Sacchi 1955, Stanton 1986; Quettier 2011; on the web helixigenic karst: http://helixigenic-karst.blogspot.com/) that they were formed by snails of the genus Helix (mazzullii, 


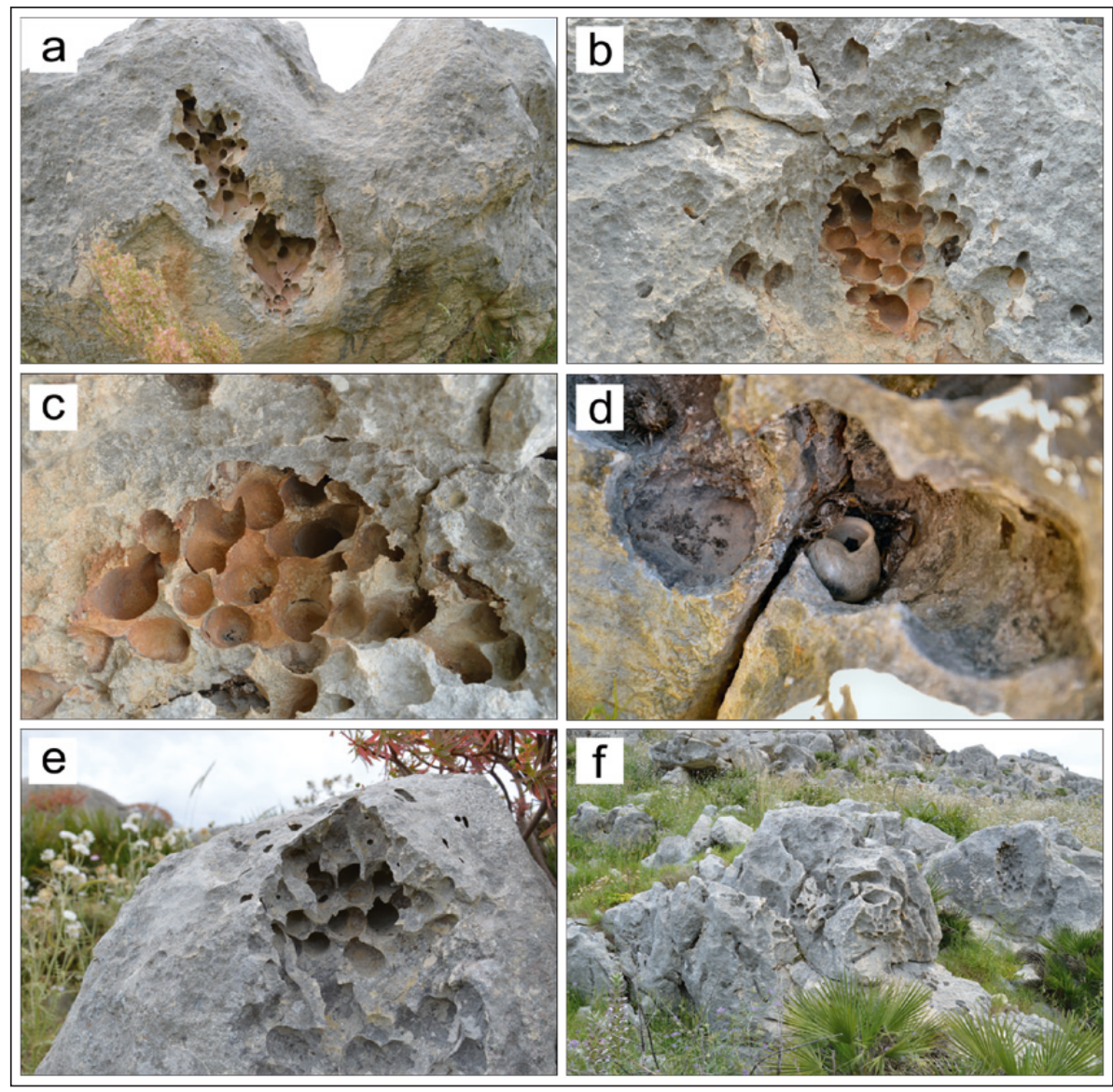

Fig. 8: Snail holes: a. - c. network of snail holes; $d$. holes with snail; $e$. and $f$. snail holes reshaping by rain and creeping water (Photo: $T$. Slabe).

aspersa) that consume calcium. The rate of rock dissolution is estimated to be $1.5 \mathrm{~mm}$ per decade. The shape of cylindrical holes, which differs from other rock forms, and their location on rock surfaces support the explanation of their origin. Quettier (2011) writes that such forms are characteristic primarily of overgrown karst surfaces. They were also able to adapt to drier environments. According to Sacchi (1955), they are a characteristic rock form of the central Mediterranean. He also provides a map of their distribution (Sacchi 1955, 640). The snails find protection in cylindrical holes from low temperatures in winter and birds and insects in summer (Quettier 2011, 204). Sacchi $(1955,641)$ notes that the environment in the holes is much cooler and more humid, an important factor in the dry and hot summer climate of the Mediterranean.

\section{ROCK FORMS CARVED BY RAINWATER}

Rain scallops and rain channels are the dominant forms, and rain flutes are only found in individual places. On rock teeth in the lower part of the karren rain scallops dominate, while cups about one centimeter in diameter on overhanging, vertical, and slanted surfaces connected in a network are the traces of even creeping of water over a larger rock surface. They initially dissect the subsoil- rounded and smooth rock. Their diverse size and shape, within the average of course, is influenced by the composition of the rock and its inclination and formation. Their lower edges are more open as a rule. On overhanging surfaces, they transform into ceiling pendants in proportion to the increasing inclination (Slabe 1995, 80). In places in the upper parts, when found on the beds of the rock with the most distinct pocket-like dissection, their edges are pronounced on vertical or steep rock to such an extent that the pendants formed on the contact points protrude a centimeter or two from the rock (Fig. 9a). Soil that creeps down together with the water and is deposited on the more gently sloping areas appears to contribute to this distinctive dissection of the rock.

Rain flutes (Fig. 9b), which are a relatively indistinct and often dissected form, unequal in length, dissect the edges of individual peaks. They develop into more regular forms and are less distinctly dissected by cups only in the middle part of the karren. As a rule, though, they are dissected by rain scallops or intertwined with their networks. This type of formation is thus dictated by the lithological characteristics (See the chapter on geology). They also dissect the walls of funnel-like notches (Fig. 9c) and the funnel-like mouths of rain channels. Most 
surfaces covered by rain flutes are found on larger rocks of the upper half of the cross-sections of karren that has been denuded for a longer period.

Where it rains on steep walls, especially on the rock of the upper half of the karren, rain channels (Fig. 9d, e) a decimeter in diameter are found running side by side. On narrow ridges where they occur on both sides, they have funnel-like mouths. Elsewhere, water from gently sloping peaks merges in them to create a composite form (Fig. 9f).
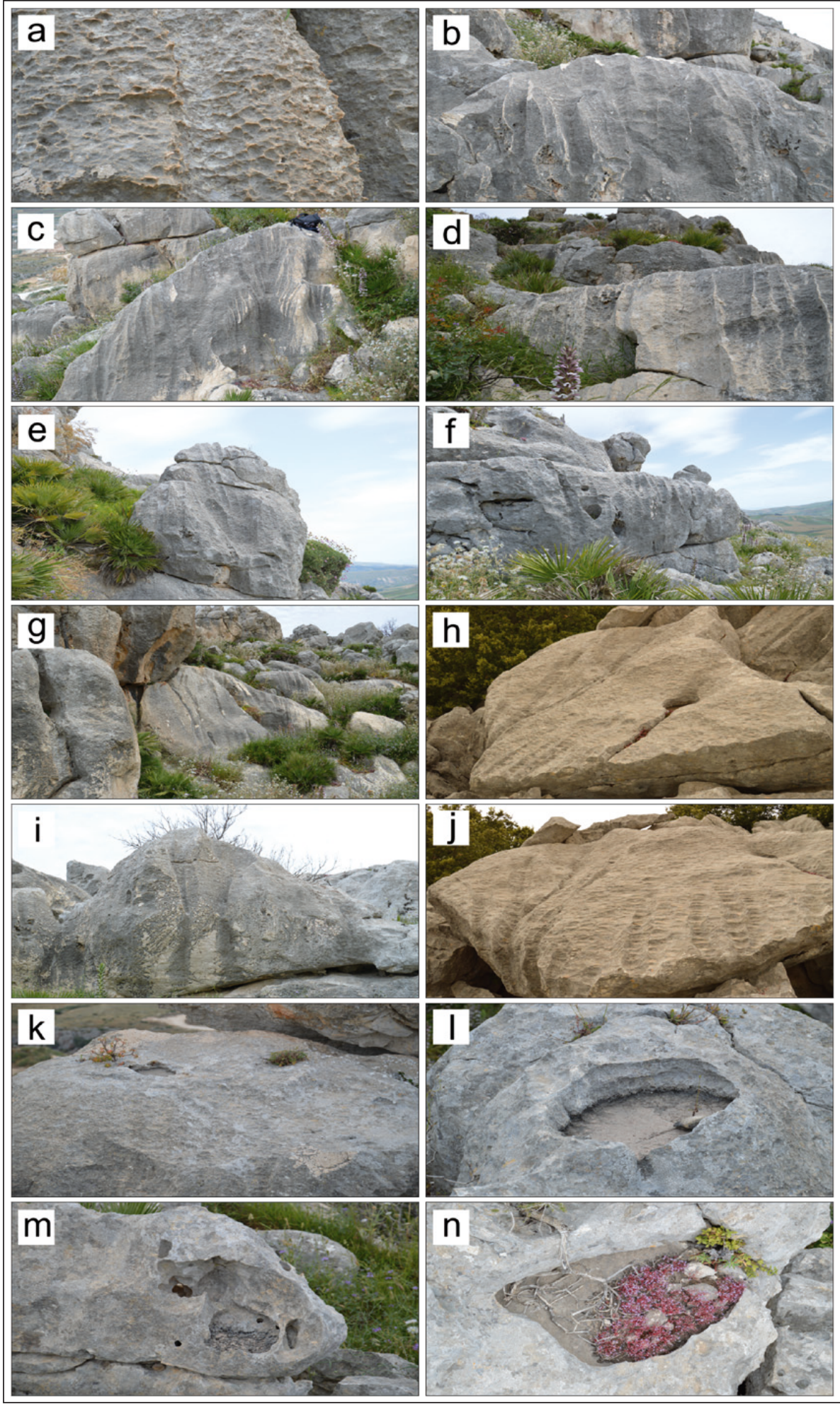

Fig. 9: Rock forms carved by rain water: a. rain scallops; $b$. rain channels and flutes; c. rain flutes on subsoil rock forms; $d$. - f. rain channels; g. wall channel below bedding plain; $h$. channels and solution pan; i. wall channel with funnellike notch; $j$. steps and channels; $k$. steps; l. - n. solution pans (Photo: T. Slabe). 
The rock relief is co-formed by water that continuously trickles on the peaks and walls of karren. The channels that lead from cavities, subsoil pockets and solution pans, and funnel-like notches function as water collectors on gently sloping peaks and lead it away. Their diameters can reach a decimeter in size. In most cases they are a composite rock form shaped by rainwater. The channels meander on gently sloping surfaces and run straight on steep surfaces. The latter are often dissected by steps whose length corresponds to the width of the channels or the bottoms of larger ones where the water flows. The densest networks are located on surfaces below bedding planes (Fig. 9g). Below vertical fissures that water flows through or on walls below subsoil pockets where water flows through the cavity, the channels most often have half-bell or bell-like beginnings. They lead from the bottom of open solution pans or water flows in them when the greater part of the solution pan is flooded. Wide channels lead from wide solution pan openings (Fig. 9h). Water that creeps relatively evenly over the entire surface of gently sloping areas often accumulates at the edge of a peak in a funnel-like notch and a channel forms below it. Gradually, bands of creeping water and then channels develop on the lowest part of gently sloping surfaces.

Below more extensive gently sloping peaks the impact of water flowing together from them dominates the formation of wall channels. In places they merge into a funnel-like notch on the wall with one channel leading from it (Fig. 9i). If they reach overhanging parts of the wall (an earlier more distinct subsoil dissection), they transform into half-bells with straight edges. Subsoil half-bells typically have circular undercut walls (Slabe \& Liu 2009). On a gently sloping wall the channels merge downwards. The walls of the channels are dissected by rain scallops that often lie crosswise across the channel and which, if they cross the entire width, are oblong in shape as dictated by the flow of the water. At the edge of a peak, individual channels can widen in a delta-like shape and divide into a number of channels. Here, one channel can become the main watercourse while the others remain hanging above it. Water from all sides flows into it, dissecting the rock three-dimensionally increasingly faster (Fig. 9j). The merging of the nearby channels produces larger funnel-like notches. As a composite rock form, shallow channels also dissect the lower sections of the walls of the wider funnel-like notches. On the walls above them there are rain flutes and channels that end with a ledge.

Steps (Fig. 9h, i, k) are found on the gently sloping surfaces of the peaks and wall ledges (Knez et al. 2015). Steps cascading one below another are located in individual longitudinal notches. They are the trace of sheets of creeping water on larger or limited surfaces. Subsoil cups millimeters in diameter dissect the floor of the steps if water also carries soil.

Solution pans are a relatively frequent rock form because the proportion of flat peaks on the karren is relatively high. They range in diameter between one centimeter and several decimeters. They are found on the peaks, either on flat peaks, the saddles between two peaks, or at their edges and at the bottom of funnel-like notches. They can be single, smaller ones inside larger ones, or several solution pans merged into one. They can be stepped (Fig. 91). Their bottoms are frequently covered by weathered debris or dissected by one-centimeter cups in most cases connected in a network and covered by weathered debris and therefore subsoil in origin. The walls of larger ones overhang as a rule, also in several levels. The smallest, whose diameters are just one or a few centimeters in size, typically develop from individual small closed cylindrical holes. Many solution pans developed from denuded subsoil cups and a network of cylindrical holes on gently sloping surfaces and at their edges. The latter have circumferences dissected by semi-circular notches. They are also found on the floor of larger cavities (Fig. 9m). These are frequently oblong in shape. Over time the solution pans open. Channels first lead from them that later are reshaped either into steps on flat surfaces or more often into funnel-like notches (Fig. 9n) that are particularly distinct at the edges of peaks or on gently sloping walls. Cavities opened on the bottoms of some.

\section{DEVELOPMENT MODEL OF KARREN}

The transformation of subsoil rock relief directly by rainwater and trickling water is the most important factor in the development model of the rock relief. The latter can be divided into water that continuously flows from rock forms (open solution pans, funnel-like notches, channels at the top) and water from cavities. The rock is gradually uncovered. On the upper part of the karren this is mostly reflected by the reshaping of funnel-like notches, and of subsoil pockets on the more gently sloping lower parts of a slope. Dominant smaller longitudinal notches indicate a relatively even lowering of the soil that covered and surrounded the rock. 


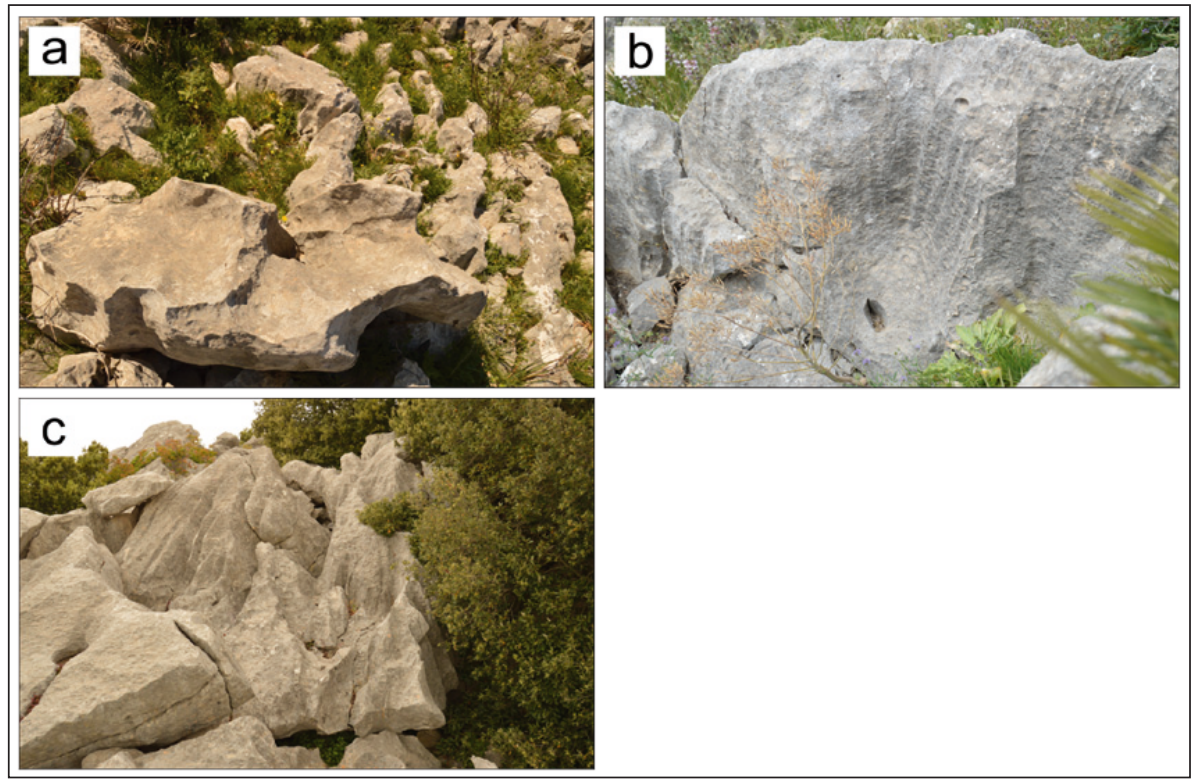

Fig. 10: Development model: a. and b. subsoil funnel-like notches reshaping by rain; $c$. steps, channels, funnel-like notches and pendants (Photo: T. Slabe).

Funnel-like notches that originated as subsoil forms are best preserved on rock surfaces that were uncovered the latest. Rainwater carved their upper parts with rain flutes and rain channels (Figs. 6d, e, f, 10a, b). Their lower parts often first had a subsoil cup filled with soil. Gradually it became denuded and formed a solution pan that as the funnel-like notch grew usually opened in the lower part into a step and a wide channel below it. Funnel-like notches also formed from subsoil pockets that opened at the edges of peaks and walls.

The second characteristic to underline is the development of the diverse rock relief of thicker beds of rock at the top of the karren and its gradual sharpening by rainwater. Relatively flat and wide tops occur due to the more rapid weathering of thin beds of rock above them and are carved by rainwater. Here small steps develop first, followed by steps (Fig. 9j, k) on which the water creeps evenly in wide belts and solution pans. Over time shallow channels form into which water flows and runs to the edges. This is where funnel-like notches occur and channels are found on the walls below them. In places several channels flow into the same notch. Funnel-like notches carved by rainwater and water trickling over the rock are not distinct but as a rule are smaller and shallow. They also form from open solution pans. They are therefore in their initial stage of formation and dissect the rock only in places. They do not dissect entire peaks, which is the rule after a long-term development of this kind and the three-dimensional dissection of peaks. Only the larger funnel-like notches are of subsoil origin. The channels that grow upwards first form on the lower parts of the surfaces and then lengthen upwards; however, in the lower part they are increasingly larger and on longer-term denuded surfaces even larger, several decimeters deep and dissecting the rock more distinctly (Fig. 9j). We can trace different stages of development on the cross-section of karren. The karren display the most distinct dissection in the upper part that has been exposed to rain for a long time and the cracks that dissect them are several meters deep. Thick and more gently sloping beds are dissected three-dimensionally. The first to appear between the channels are longitudinal, increasingly sharper ridges (Fig. 10c) that eventually dissect into pendants (Knez et al. 2015).

Larger surfaces of walls on rock of uniform composition strongly suggest that a characteristic rock relief carved by rainwater and water trickling down the walls forms over subsoil funnel-like notches and wall channels. Below the ridge that is partially dissected by funnel-like notches there are rain flutes and rain channels on the wall; in the middle part the rock is relatively smooth, and lower there are channels where water flows together from the upper parts of the walls. Flutes also dissect the ridges across the wall. This is the same rock relief formed by laboratory modeling on plaster (Slabe 2009, 52).

The dissolution of the rock opens the cavities and shapes their remaining parts. These forms can be called unroofed cavities.

\section{CONCLUSION}

The studied profile displays alternating beds of calcarenite and calcirudite. All the beds are distinguished by a high content of total carbonate, with the lowest content always higher than $95 \%$. The average value of dolomite and insoluble residue is only a few percent. The rock has a distinct impact on the occurrence and formation of 
smaller rock forms (rain flutes, rain scallops); in places, the size of grains in the rock affects the development of larger rock forms as well.

Karren and smaller stone forests develop from subsoil karren. The development of the latter is evident in distinctly developed subsoil rock forms ranging from subsoil cavities that in places densely hollow the rock and traces of vertical percolation of water through the soil such as subsoil funnel-like notches and channels to longitudinal notches representing the traces of longterm levels of soil surrounding the rock. Subsoil cups and channels form on horizontal and gently sloping areas that in places are covered by soil.

Denuded rock with subsoil rock relief is transformed by rainwater and water trickling down the walls and flowing through the rock and from cavities in the walls.

Sharper peaks of rock teeth that developed on thicker beds of rock are mostly subsoil forms that have been only partly transformed by rainwater. Large funnel-like notches often bear witness to this. We can assume the relatively young denudation of the karren or at least of their lower parts. Solution pans mostly developed from subsoil cups. The wider peaks are often flat. They formed where thinner beds of rock lying above thicker ones decomposed. On such peaks the water creeps over larger surfaces and flows over the edge to the walls. The funnel-like notches that developed at the edges are relatively small. Rain flutes only occurred on individual places and are relatively indistinct forms dictated primarily by lithological characteristics. Rain scallops often dominate. A flat surface, which in this development model is first dissected by channels and funnel-like notches therefore gradually dissects into a pointed surface. We can observe the initial periods of development.

Systems of cylindrical holes of biocorrosion, helixigenic origin give a special stamp to the rock relief of this karren. They are a characteristic of the rock surface in the wider environment of karst development.

\section{ACKNOWLEDGEMENT}

The authors acknowledge the financial support from the Slovenian Research Agency (research core funding No. P6-0119). Research was supported and included in the framework of the UNESCO IGCP project No. 661 and UNESCO Chair on Karst Education.

\section{LITERATURE}

Abate, B., Di Maggio, C., Incandela, A. \& P. Renda, 1991: Nuovi dati sulla geologia della Penisola di Capo San Vito (Sicilia nord-occidentale).- Mem. Soc. Geol. It., 47, 15-25.

Abate, B., Di Maggio, C., Incandela, A. \& P. Renda, 1993: Carta Geologica dei Monti di Capo San Vito, scala 1:25.000.- Dip. Geologia e Geodesia dell'Università di Palermo.

Abate, B., Incandela, A., Renda, P. \& M. Tramutoli, 1996: Facies ed evoluzione sedimentaria del "Bacino di Trapani” (Sicilia occidentale) durante l'OligoceneMiocene.- Mem. Soc. Geol. It., 51, 119-128.

Abate, B., Incandela, A., Nigro, F. \& P. Renda, 1998: Plio-Pleistocene strike-slip tectonics in the Trapani Mtd. (NW Sicily).- Boll. Soc. Geol. It., 117, 555-567.

Bianchi, F., Carbone, S., Grasso, M., Invernizzi, G., Lentini, F., Longaretti, G., Merlini, S. \& F. Mostardini, 1987: Sicilia orientale: profilo geologico NebrodiIblei.- Mem. Soc. Geol. It., 38, 429-458.
Broquet, P. \& G. Mascle, 1972: Les grands traits stratigraphiques et structuraux de la partien septentrionale des Monts de Trapani (Sicile occidentale).Ann. Soc. Geol. Nord, XCII, 3, 139-146.

Catalano, R. \& B. D’Argenio, 1978: An essay of palinspastic restoration across the western Sicily.- Geol Romana 17, 145-159.

Catalano, R. \& B. D’Argenio, 1982: Schema geologico della Sicilia.- In: Catalano \& B. D’Argenio (eds.), Guida alla geologia della Sicilia Occidentale, Soc. Geol. It., Palermo.

Catalano, R., Franchino, A., Merlini, S. \& A. Sulli, 2000: Central western Sicily structural setting interpreted from seismic reflection profiles.- Mem. Soc. Geol. It., 55, 5-16.

Catalano, F., Agate, M., Basilone, L., Di Maggio, C., Mancuso, M. \& A. Sulli, 2011: Note illustrative della Carta Geologica d'Italia alla scala 1:50.000, foglio 593 Castellammare del Golfo.- ISPRA, Servizio Geologico d'Italia. Regione Siciliana Ass. Territorio Ambiente. 
Engelhardt, W., Füchtbauer, H. \& G. Müller, 1964: Sediment-Petrologie, Methoden der Sediment-Untersuchung, Teil 1.- E. Schweizerbart'sche Verlagsbuchhandlung (Nägele u. Obermiller), pp. 303, Stuttgart.

Evamy, B.D. \& D.J. Sherman, 1962: The application of chemical staining techniques to the study of diagenesis of limestones.- Proc. Geol. Soc. London, 1599, 102-103.

Giunta, G. \& V. Liguori, 1972: Geologia della estremità Nord-occidentale della Sicilia.- Riv. Min. Sic., 13, 165-226.

http://helixigenic-karst.blogspot.com/

Incandela, A., 1995: Lineamenti stratigrafico-strutturali dell'estremità nord-occidentale della Sicilia e delle isole di Favignana e Levanzo (Arcipelago delle Egadi).- Tesi di Dottorato, Palermo.

Mietto, P. \& U. Sauro, 2003: Le pareti nei calcari oligocenici.- Grotte dei Berici. Aspetti fisici e naturalistici, $1,35-40$.

Munsell Color, 2009: Geological Rock-Color Chart.Munsell Color, Grand Rapids, MI, USA.

Nigro, F. \& G. Renda, 2005: Transtensional/extensional fault activity from the Mesozoic rifting to Tertiary chain building in Northern Sicily (Central Mediterranean).- Geologica Carpathica, 56, 3, 255-271.

Nigro, F., Renda, P. \& G. Arisco, 2000: Tettonica recente nella Sicilia nord-occidentale e nelle isole Egadi.Boll. Soc. Geol. Ot., 119, 307-319.

Knez, M., Rubinić, J., Slabe, T. \& E. Šegina, 2015: Karren in the Kamenjak Hum (Dalmatian Karst, Croatia); from its initial dissection of flat surfaces by rain to rock points.- Acta carsologica, 44, 2, 191-201.

Ogniben, L., 1960: Nota illustrativa dello schema geologico della Sicilia nord-orientale.- Riserva Mineraria Siciliana, 11, 183-212.

Oldow, J. S., Channel, J .E. T., Catalano, R. \& B. D’Argenio, 1989: Contemporaneous thrusting and large-scale rotation in the Western Sicilian fold and thrust belt.Tectonics, 9, 661-681.
Quettier, D., 2011: Observations on the saxicavous habits of Cepaea nemoralis (Linnaeus, 1758) (Pulmonata, Stylommatophora, Helicidae) in the Pyrenees (France).- Biodiversity Journal, 2, 4, 201-206.

Roure, F., Howell, D. G., Muller, C. \& I. Moretti, 1990: Late Cenozoic subduction complex of Sicily.- Journ. Struct. Geology 12, 2, 259-266. DOI: 10.1016/01918141(90)90009-N

Ruggieri, R., 2009: Karst Itinerary and cave discovery in the Zingaro Reserve.- Azienda Foreste Demaniali, Palermo, pp. 207.

Ruggieri, R., 2015: Speleological and Speleogenetic aspect of the Monti di Capo San Vito, (Sicily): influence of morpho-tectonic evolution.- Ph.D. theses, University of Nova Gorica, Springer edition, $267 \mathrm{pp}$. DOI: 10.1007/978-3-319-21720-8

Sacchi, C. F., 1955: Fattori ecologici e fenomeni microevolutivi nei Mollusci della montagna mediterranea.Bolletino di zoologia, 22, 2, 663-652.

Slabe, T., 1995: Cave Rocky Relief.- Zbirka ZRC 10, pp.128, Ljubljana.

Slabe, T., 2009: Karren simulation with plaster of Paris models.- In: Gines, A., et al. (eds.) Karst Rock Features - karren sculpturing. ZRC Publishing, pp. 4754, Postojna - Ljubljana.

Slabe, T. \& H. Liu, 2009: Significant subsoil rock forms.In: Gines, A., et al. (eds.) Karst Rock Features - karren sculpturing. ZRC Publishing, pp. 123 - 137, Postojna - Ljubljana.

Stanton, W. I, 1986: Snail Holes (Helixigenic Cavities) in Hard Limestone- an aid to the interpretation of Karst Landforms.- Proceedings University of Bristol Spelaeological Society 17, 3 .

Tondi, E., 2007: Nucleation, development and petrophysical properties of faults in carbonate grainstone: Evidence from the San Vito Lo Capo peninsula (Sicily, Italy).- Journal of Structural Geology, 29, 614-628. DOI: 10.1016/j.jsg.2006.11.006 